\title{
Comparative analysis of career choices by students in Latvia and the UK
}

\author{
Bikse, Veronika; Lūsēna - Ezera, Inese; Libkovska, Una and Rivža, Baiba \\ Liepaja University, Latvia
}

\begin{abstract}
The purpose of this research study is to examine theoretical findings and, based on them, to identify the career choice factors that affect Latvian and UK secondary school students' occupational interests. The research was based on the theoretical concepts of the occupational interests, and the data gained from a survey of Latvian and UK secondary school students. The results of the research indicate that the most essential factors that help individuals to choose a career is to understand their own interests and explore their own capabilities. Also, learning experience and parents' advice is important for them. The occupational interests of the students, who were interviewed, are not harmonized with the demand in the economy.
\end{abstract}

Keywords: career choice, education institutions, labour market trends, occupational interests, students. 


\section{Introduction}

The world of work has undergone rapid change in recent decades. ICT has dramatically changed how we live and work and how economies are structured (GEM Report 2016). Employment opportunities continue changing, and only the ability to understand developments, acquire and use information, general and professional knowledge and skills allow adapting to the changes fast and affectively. All these changes directly relate to the new generation that have to think of their choices of careers and education, as their individual growth and competitiveness in the labour market depend on that.

The importance of this issue has increased nowadays because, firstly, the development and competitiveness of the national economy, as never before, depends on the developed human capital, people's professionalism, interest to work actively and being innovative. Only work, corresponding to a person's abilities, desires and interests, can ensure real creativity and successful work in a definite field. It means that the choice of a career has always been and will be a topical issue and an important behaviour component taking part in one's life to set his/her goal to achieve the career. (Kumar, 2016) Secondly, forecasting and analysing this century's priorities, the correspondence of career choices by the youth to labour market trends and the role of career education are increasingly discussed. It is difficult for the youth to be competent in the broad diversity of professions, be aware of their talents and abilities as well as harmonise them with labour market requirements without the advice of adults. Under such circumstances, the role of comprehensive education increases, with the greatest focus being placed on career education, shaping school students' professional interests and harmonising their talents and skills with labour market trends.

\section{Literature review on factors influencing the career choice}

Various factors affect career choices of high school students. The review of the literature has showed that a number of different factors characterizing the impact on decision making by students of their career choices can be found. Having studied them, the conclusion is that, except for a few differences, all the authors include more or less the same factors such as: personality, interests, friends, parents, teachers, social status, prestige, career satisfactions, socio-economic factors, cultural identity, globalization, family business and others. (Kumar, 2016; Pascual, 2014; Fizer, 2013; Edwards, 2011) Other authors, for example Borchert (2002), have made a summary of different factors in three major areas affecting career choice: environment, opportunity and personality. Environment includes the forces of family, political, social, and economic issues. Opportunity - the issue of poverty; the income level of families may determine what career a student chooses during a specific time in the student's life. Personality - a characteristic way of thinking, feeling (attitudes and opinions) and behaving must be a self-motivated type; investigating career 
possibilities from early years of the life plays an important role in the choosing of the right career. Summarizing the research done on the career choice factors by aforesaid authors, it is important to mention that there are the interrelationships of psychological, economic, cultural and sociological determinants of career choice decision making (Lombardo). Our position on the above-mentioned determinants identified by various authors could be supported in general. Before choosing a career, an important prerequisite is the formation of professional interests or the coordinated identification of the personality's interests, wishes, abilities and skills and the challenges of the 21 st century and labour market trends. This means that all the mentioned determinants of career choice have to be taken into account, as well as their interactions.

As regards the concept of occupational interests, it consists of two components: occupational and interests. According to the English Cobuild dictionary, occupational means relating to a person's job or profession. (English Cobuild dictionary) However, a pedagogical term dictionary explains the word interests as an active attitude determined by needs, experience and choices to the objects of reality; it is a manifestation of human cognition, which directs the mental activity towards a certain object. (Pedagogical term dictionary, 1978) The concept of interests can be defined using a wide range of criteria, depending on what objects and subjects are examined.

According to Watts (2008) and OECD (2004), occupational interests consist of three broad categories: learning goals which include improving the efficiency of the education and training system, and managing its interface with the labour market; labour market goals these include improving the match between supply and demand, and managing adjustments to change; social equity goals - these include supporting equal opportunities and promoting social inclusion. A challenge for all countries is to maintain an appropriate balance between them in the provision of services. A more detailed description on the concept of occupational interests is given by the Career and Employability Centre indicating that interests and motivations is a key stage in career exploration. It can help to formulate ideas about different job roles and it can be helpful to think about:

- $\quad$ personality - what are you like as an individual? what types of roles or workplaces would suit you?

- $\quad$ abilities and skills - what are you good at? what skills have you developed throughout your life so far?

- interests - what do you enjoy doing? what kind of careers appeal to you? (Careers and Employability Centre)

- values - what do you care about? what is important to you?

After summarising all the above, one can conclude that occupational interests are a prerequisite for the choice of a profession, as the process of formation of occupational 
interests helps people clarify their [occupational interests] and preferences towards making these important decisions. This may be at the beginning of their working lives, but is also useful if people want to change or develop their careers or to explore options around professional specialization (Occupational choice). Accordingly, the authors of the paper believe that the concept of occupational interests needs to be developed and it could be defined as follows: occupational interests represent the individual's self-cognition that allows identifying the wishes, abilities and specific skills that determine the choice of a career (field of activity) according to the challenges of the 21 st century and labour market trends. In order that occupational interests materialise into the choice of a particular career, they have to be shaped. It has to be understood that the formation of occupational interests represents a complex set of activities aimed at developing individual careers and helping to choose education and a career, which, in its turn, allows the personality to grow and get satisfaction from the job. To tackle this problem and successfully choose a career, it is important to design a career education programme that provides opportunities to achieve a real goal and results, which is possible if all interested individuals cooperate in an understandable, creative and democratic environment in order to transfer knowledge and built up necessary skills.

\section{Research methodology and participants}

The research methodology implemented for this research study involves an analysis of different career choice factors that affect Latvian and UK secondary school students' occupational interests. In order to find out about this, a comparative study was carried out within the present research on the basis of two different surveys of students: 1) survey of students carried out in Latvia and performed in 2015 by the State Education Development Agency. 1064 young people aged 14 to 19 were interviewed via the Internet website Draugiem.lv (State Education Development Agency, 2015) and 2) survey of students in the UK carried out by the market research agency YouGov in the UK questioning 3,154 young people aged between 14 and 19 via YouGov's online research panel on 10 September 2015 and 22 September 2015 asking them about their career choices and considering the future of the UK jobs market. The survey was carried and weighted to be representative of the UK sample aged 14-19 years (City \& Guilds, 2015). The comparison of the surveys of UK and Latvian students was performed to identify the youth's professional interests in two European Union Member States with significantly different standards of living and economic development levels: according to the World Bank data for 2016, GNI per capita in the UK in the US dollar value - 42,360; while in Latvia - 14,570 or 2.9 times lower. (World Bank Country and Lending Groups) 


\section{Research findings}

The preparedness of young people to integrate into the labour market means developing their occupational interests, so that they are successful in choosing their careers and the further education field. To find out whether the occupational interests of youth correspond to the labour market requirements, comparative analysis was used in the study performed on the basis of student surveys that were carried out in Latvia and in the UK. Secondary school students' responses have been summarised in Figure 1.

As shown in Figure 1, over $68.1 \%$ of Latvia's respondents considered personal interest in influencing an individual's career choice important because they believed the most important thing was to understand their own interests and explore their own capabilities. In contrast to the UK survey results, only $36.0 \%$ of the students stated this fact. These results are in agreement with those of Edwards (2011) and Borchert (2002) who reported that when choosing careers, most students consider their interests.

Our research also indicates that young people do not see career advice as important. Of the UK youth, only 5\% said that a careers advisor would help the most in getting a job they would be satisfied with, and when asked why they were thinking of a particular career, only $14 \%$ said that a careers advisor had recommended it. A comparison of the responses of Latvia's respondents reveals that the role of career consultations in choosing one's future career was less important: only $1.6 \%$ respondents considered that a careers advisor would help with career choices (Figure 1).

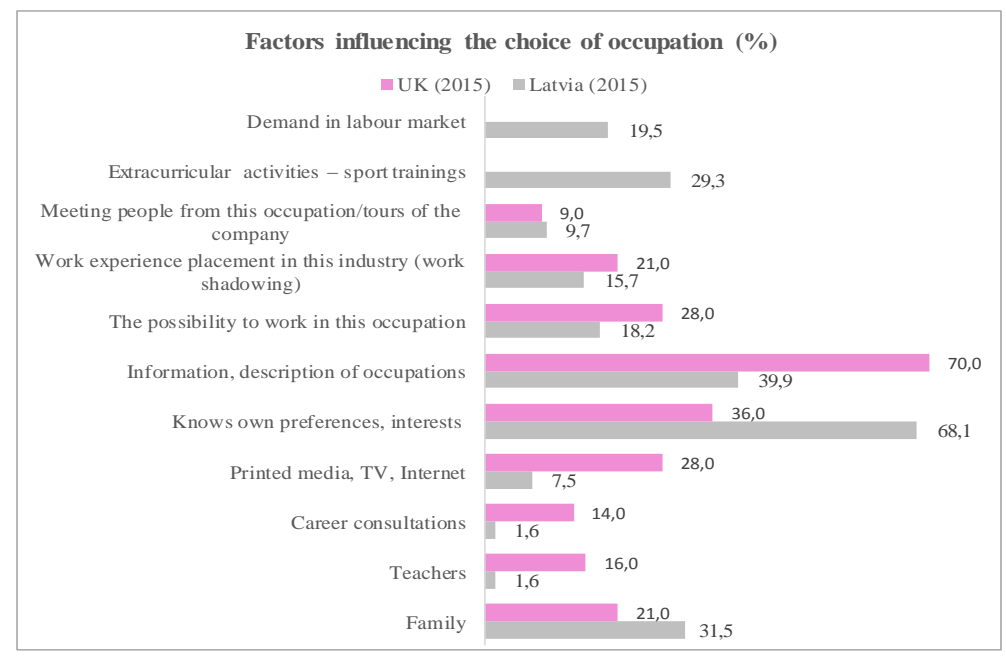

Figure 1. Comparative analysis of the student surveys on career choice factors in Latvia and the UK. Source: authors' compilation based on the State Education Development Agency data, 2015 and City \& Guilds, 2015 
As mentioned above, when choosing one's career, it is important to align one's interests and capabilities with the needs of the economy. According to the survey data, only $19.5 \%$ of Latvia's respondents took into account the demand in the labour market and the trends when choosing their career. Moreover, 35.9\% respondents noted that the information about occupational opportunities was not sufficient to help them make appropriate career choices. Moreover, just $7.5 \%$ of Latvia's respondents said that the printed media, TV, the Internet were an important information factor. Nearly all of Latvia's respondents admitted that they needed some help in getting information about the contents of the career and remuneration, as well as the labour market development trends and education institutions that provided training opportunities. According to the UK survey results, $70.0 \%$ respondents stated that information and the printed media, TV, the Internet $(28 \%)$ were the main factor that impacted decision making by students of career choices. It has to be mentioned that the information - about the self, about education and training opportunities, about occupations and their characteristics, about the labour market supply and demand - was central to notions such as the self-concept and career decidedness. Information on the labour market supply and demand, including local and regional information as well as national information, is an essential element of career information. (OECD, 2004)

To choose an occupation, it is essential to find out if the learning experience of a student has any influence on his or her career choice. The results in Figure 1 show that hands-on experience built up by getting engaged in summer jobs and extracurricular activities, visiting companies/institutions and meeting people of the particular occupation was also of great importance in taking a decision. Responding to the question: "In your opinion, how can one get the most extensive information about different occupations in order to learn about them?" of Latvia's respondents, $41 \%$ said that meeting and talking to people working in this occupation was the most important factor (State Education Development Agency, 2015). Comparing the responses of UK respondents about their career aspirations, it was find out that the good exam results (58\%) and going to university $(39 \%)$ was the best route to a good career, instead of apprenticeships (19\%) or a professional qualification or training (13\%) (City \& Guilds, 2015).

Thus, we can conclude that the factor that most influenced the students' choices was their personal interests. At the same time, the authors consider that it is important to choose an occupation that is in line not only with one's personal interests but also with the needs of the economy as well. Otherwise, one might have to work in a job that does not correspond to the qualification acquired. 


\section{Conclusion and recommendations for a future study}

The research findings show that before choosing a career, an important prerequisite is the formation of occupational interests or coordinated identification of the personality's interests, wishes, abilities and skills and the challenges of the 21 st century and labour market trends.

Based on the analysis of the surveys of students on the factors that impact decision making by the students of their career choices, it was found out that in the process of formation of occupational interests, the youth's wishes, talents and skills were not harmonized with the needs of the economy. Latvia's high school students, when choosing their future careers, were mainly guided by their own personal interests. Also, learning experience and parents' advice were important for them. At the same time, the requirements of the labour market were not considered to be an important factor. It means that Latvia's students need some help in getting information about the contents of the labour market development trends and education institutions that provide training opportunities. However, $70 \%$ of the UK students were confident they had all the information they needed to make an informed choice about their career. At the same time, it was concluded that young people weren't getting objective information on careers (City \& Guilds, 2015). This suggests that career education activities at comprehensive schools are inadequate.

The future demand and supply situation in the labour market depends on today's decisions made by young people when choosing their careers. In this context, it is important to take into account that students' occupational interests are closely linked to their decisions both in relation to the choice of courses in high school and about their studies in higher education (Germeijs and Verschueren, 2006) and these decisions can affect their future career. Therefore, it is necessary to implement better targeted activities in career education and to establish closer links between the education system and the labour market. Similar to the results of this study, Ukil (2016) found that there was a significant correlation between career education and the occupational interests of youth. At the same time, the authors consider that it is necessary to do more research on occupational interests of youth, career choices by higher education institution students and their correspondence to labour market trends.

\section{Acknowledgments}

The preparation of the paper was supported by the National Research Programme 5.2. Project EKOSOC_LV. 


\section{References}

Borchert, M. (2002). Career choice factors of high school students. A Research Paper. Retrieved from http://www2.uwstout.edu/content/lib/thesis/2002/2002borchertm.pdf

Careers and Employability Centre. Your interests and motivations. Retrieved from http://www.sussex.ac.uk/careers/careerchoices/interests

City \& Guilds. (2015). Great Expectations, Great Britain. Teenagers' career aspirations versus the reality of the UK jobs market.

GEM Report. (2016). Education for people and planet: creating sustainable futures for all. UNESCO, second edition published in 2016 by the United Nations Educational, Scientific and Cultural organization.

Germeijs, V. and Verschueren, K. (2006). High School Students' Career Decision Making Process: Development and Validation of the Study Choice Task Inventory. Journal of Career Assessment, Vol. 14 (4), 449-471

Edwards, K. and Quinter, M. (2011). Factors Influencing Students Career Choices among Secondary School students in Kisumu Municipality, Kenya. Journal of Emerging Trends in Educational Research and Policy Studies (JETERAPS), 2(2), 81-87

English Cobuild dictionary. Retrieved from http://dictionary.reverso.net/englishcobuild/occupational\%20interests

Fizer, D. (2013). Factors Affecting Career Choices of College Students Enrolled in Agriculture. A Research Paper Presented for the Master of Science in Agriculture and Natural Resources Degree. The University of Tennessee, Martin. December 2013. Retrieved

from http://www.utm.edu/departments/msanr/_pdfs/Fizer_Research_Project_Final.pdf

Kumar, S. (2016). Career Choice and College Students: Parental Influence on Career Choice Traditionalism among College Students in Selected Cities in Ethiopia. International Journal of Psychology and Educational Studies, 3(3), 23-30.

Lombardo, J. Factors Affecting Occupational Choice: Psychological, Social, Economic, and Cultural. Retrieved from https://study.com/academy/lesson/factors-affectingoccupational-choice-psychological-social-economic-and-cultural.html

OECD (2004). Career Guidance and Public Policy: Bridging the Gap, OECD Publishing, Paris.

$\begin{array}{lll}\text { Occupational } & \text { interests. } & \text { Retrieved }\end{array}$ http://psychology.wikia.com/wiki/Occupational_interests

Occupational choice. Retrieved from http://psychology.wikia.com/wiki/Occupational_choice

Pascual, N. T. (2014). Factors Affecting High School Students' Career Preference: A Basis for Career Planning Program. International Journal of Sciences: Basic and Applied Research, 16(1), 1-14

Pedagogical term dictionary. Riga, Liesma, 1978.

State Education Development Agency (2015). Open the door to your future occupation! Retrieved from https://infogr.am/viaa_aptauja_2015. 
Ukil, M.I. (2016). Career barriers to career indecision: a final-year BBA student view. Polish journal of Management studies, 13(1), 192-205.

Watts, A.G. (2008). Career Guidance and Public Policy. In: Athanasou J.A., Van Esbroeck R. (eds) International Handbook of Career Guidance. Springer, Dordrecht, Pages 341-353.

World Bank Country and Lending Groups. Retrieved from https://datahelpdesk.worldbank.org/knowledgebase/articles/906519-world-bankcountry-and-lending-groups 